\title{
DEPTH OF CURE OF DENTAL COMPOSITES SUBMITTED TO DIFFERENT LIGHT-CURING MODES
}

\author{
PROFUNDIDADE DE POLIMERIZAÇÃO DE COMPÓSITOS RESTAURADORES \\ SUBMETIDOS A DIFERENTES MÉTODOS DE FOTOATIVAÇÃO
}

Raphael Vieira MONTE ALTO ${ }^{1}$, José Guilherme Antunes GUIMARÃES², Laiza Tatiana POSKUS², Eduardo Moreira da SILVA²

1- DDS, Graduate Student (Master Degree), Department of Restorative Dentistry, School of Dentistry, Federal Fluminense, Niterói, RJ.

2- PhD, Associate Professor, Department of Restorative Dentistry, School Of Dentistry, Federal Fluminense University, Niterói, $R J$.

Corresponding address: Eduardo Moreira da Silva - Universidade Federal Fluminense - Faculdade de Odontologia - Rua Presidente Pedreira, 97/904 - Ingá, Niterói, RJ - Cep.: 24470 - Phone: (21) 2629-9832 - Fax: (21) 2622-5739 - e-mail: emsilva@vm.uff.br

Received: December 2, 2004 - Modification: June 15, 2005 - Accepted: December 21, 2005

\begin{abstract}
Q

bjective: This study evaluated the depth of cure of five dental composites submitted to different light-curing modes. Material and Methods: Canal-shaped cavities with $5 \mathrm{~mm}$ of length were prepared on the buccal surfaces of extracted third molars, and restored using P-60, A-110, Admira, Z-250 and Supreme resin composites. Materials were light-cured from the top, according to three modes (Group 1- Conventional (C): $500 \mathrm{~mW} / \mathrm{cm}^{2} / 40 \mathrm{~s}$; Group 2 - Soft-Start (SS): $250 \mathrm{~mW} / \mathrm{cm}^{2} / 20 \mathrm{~s}+500$ $\mathrm{mW} / \mathrm{cm}^{2} / 20 \mathrm{~s}+500 \mathrm{~mW} / \mathrm{cm}^{2} / 10 \mathrm{~s}$ and Group 3 - LED: $250 \mathrm{~mW} / \mathrm{cm}^{2} / 40 \mathrm{~s}$ ). After that, cavity longitudinal surfaces were polished and marked with a millimeter scale of $4 \mathrm{~mm}$ of length. Depth of cure was evaluated by means of Knoop hardness number (KHN), so that five indentations were performed at each millimeter. Original data were submitted to three-way ANOVA and Fisher's LSD test $(\alpha=0.01)$. Results: All materials presented a significant reduction on KHN from first to third millimeter. Regarding depth of cure, the results obtained for Conventional and Soft-Start modes were similar, but statistically superiors to those found for group 3 (LED). Conclusion: This performance may be related to the differences among energy densities obtained with different light-curing modes.
\end{abstract}

Uniterms: Composite resins; Depth of cure; Light curing modes; Softstart polymerization; Microhardness.

\section{RESUMO}

$O$

bjetivo: Este estudo avaliou a profundidade de polimerização de cinco compósitos fotopolimerizáveis submetidos a diferentes métodos de fotoativação. Material e Método: Cavidades em forma de canaleta com 5 mm de comprimento, preparadas nas faces vestibulares de terceiros molares, foram restauradas com os compósitos P-60, A-110, Admira, Z-250 e Supreme. Os materiais foram fotoativados pelo topo das cavidades com três técnicas (Grupo 1 - Convencional (C): $500 \mathrm{~mW} / \mathrm{cm}^{2} / 40 \mathrm{~s}$; Grupo 2 - Soft-Start (SS): $250 \mathrm{~mW} / \mathrm{cm}^{2} / 20 \mathrm{~s}+500 \mathrm{~mW} / \mathrm{cm}^{2} / 20 \mathrm{~s}+500 \mathrm{~mW} / \mathrm{cm}^{2} / 10$ s e Grupo 3 - LED: $250 \mathrm{~mW} / \mathrm{cm}^{2} / 40$ s). Após a fotoativação, as superfícies longitudinais dos materiais foram polidas e marcadas com uma escala milimetrada com $4 \mathrm{~mm}$ de comprimento. A profundidade de polimerização foi avaliada através do número de dureza Knoop (NDK), com cinco indentações a cada milímetro. Os dados originais foram submetidos à Análise de Variância de três fatores e teste de Fisher para comparações entre médias $(\alpha=0,01)$. Resultados: Todos os materiais apresentaram diminuição do NDK do primeiro para o terceiro milímetro $(\mathrm{p}<0,01)$. Os resultados obtidos com os Grupos Convencional e Soft-Start foram similares e superiores ao Grupo LED $(p<0,01)$. Conclusão: Este desempenho pode ser relacionado às diferenças nas densidades de energia obtidas com os métodos de fotoativação utilizados.

Unitermos: Resinas compostas; Profundidade de polimerização; Métodos de fotoativação; Polimerização gradual; Microdureza. 


\section{INTRODUCTION}

In the last years, restorative dentistry has undergone an exponential evolution. One of the greatest advances was the synthesis of Bis-GMA molecule (2,2-bis[4-(2-hydroxi-3methacrylyloxypropoxy)phenyl]propane) and introduction of a surface treatment technique of filler particles using a silane agent ${ }^{5}$. This evolution allowed the development of restorative composite materials with excellent physical and chemical properties, and better clinical performance. However, the presence of two aromatic rings and inherent high molecular weight of Bis-GMA molecules make this monomer present low mobility and increased viscosity, thus reducing the capacity of filler incorporation and degree of monomer conversion in composite materials that have this molecule as part of their organic matrix ${ }^{11}$. Therefore, low molecular weight monomers, such as TEGDMA (triethyleneglycol dimethacrylate), are added to the organic matrix to reduce viscosity and enhance filler particle concentration $^{2,6}$. Other organic matrices were also developed in an attempt to improve the properties of resin composites. UEDMA (1,6-bis(methacrylyloxi-2-ethoxycarbonylamino)2,4,4-trimethylexane) is a monomer that presents long linear chain without aromatic rings, thus presenting more flexibility than Bis-GMA, and consequently greater degree of conversion $^{27}$. Non-hydroxylated monomers, such as BisEMA (2,2-bis[4-(2methacrylyloxyethoxi)phenyl] propane) were introduced to reduce water sorption by the organic matrix, leading to enhanced mechanical properties ${ }^{28}$. The organic matrix of present light-cured resin composites are constituted of a mixture of all these monomers in varying proportions $^{23}$. In conjunction with type, size and concentration of filler particles, this organic matrix has direct influence on the degree of conversion and mechanical properties of composite materials ${ }^{1,13}$.

Nowadays these materials are polymerized using halogen light-curing units that irradiate blue light with a wavelength between 400-500 nm. These units may allow constant light irradiation or present progressive modes that initiate with a low irradiation and reach values around $900 \mathrm{~mW} / \mathrm{cm}^{2}{ }^{15}$. However, disadvantages related to this type of light-curing method may be heat generation during material polymerization, which may cause damage to pulp tissues, and loss of efficiency due to bulb wear, resulting in a reduction in the degree of conversion and mechanical properties of the material ${ }^{19}$.

Recently, light-curing units that present light emission diodes (LEDs) have been advocated as presenting greater efficacy on the polymerization of light-cured composites ${ }^{14,30}$. These units irradiate light with a wavelength close to 4680 $\mathrm{nm}$, which is the absorption peak of camphorquinone, a photoinitiator present in most present composites. Advantages related to these light-curing units may be absence of heat generation during material polymerization and improved life.

This study evaluated the depth of cure of five resin composite materials with different compositions, submitted to three light-curing modes. The hypothesis was that the organic monomer matrix composition, type and concentration of filler particles and light-curing method would influence the depth of cure of resin composite materials.

\section{MATERIALAND METHODS}

The present study was approved by Research Ethics Committee (Medical Science Center - Federal Fluminense University).

Five light-cured dental composites with different formulations were tested in this experiment: P-60, A-110, Admira, Supreme and Z-250. Composite compositions can be found on Table 1.

\section{Specimen preparation}

Thirty recently extracted sound human molars were maintained refrigerated in $1 \%$ chloramine solution for disinfection for a maximum period of 1 month prior to the experiment. Buccal and occlusal surfaces were flattened in a polishing machine (DPU-10, Struers, Copenhagen, Denmark) using 150 and 600-grit sandpapers (3M, Campinas, SP, Brazil) under water refrigeration, until a superficial flat dentin surface was exposed. Canal-shaped cavities with $5 \mathrm{~mm}$ of length were prepared on the buccal surfaces of the molars, using a 4103 cylindrical diamond bur (KG, Alphaville, São Paulo, SP, Brazil). Half of the teeth received 3 cavities and the other half 2 cavities. Cavities were restored with dental composite and the buccal surfaces of the teeth were covered with a polyester strip and an additional molar that had one of its surfaces flattened, allowing light penetration only by an occlusal opening during light-curing procedures. The additional molar was maintained by manual pressure and the composites were light-cured according to the following experimental protocol: Group 1 - Conventional (C): constant irradiation of $500 \mathrm{~mW} / \mathrm{cm}^{2} / 40 \mathrm{~s}$ (Degulux Soft-Start, Degussa-Hüls, Hanau, Germany); Group 2 - Soft-Start (SS): $250 \mathrm{~mW} / \mathrm{cm}^{2} / 20 \mathrm{~s}+500 \mathrm{~mW} / \mathrm{cm}^{2} / 20 \mathrm{~s}+500 \mathrm{~mW} / \mathrm{cm}^{2} / 10 \mathrm{~s}$ (Degulux Soft-Start, Degussa-Hüls, Hanau, Germany) and Group 3 - LED: constant irradiation of $250 \mathrm{~mW} / \mathrm{cm}^{2} / 40 \mathrm{~s}$ (Ultraled, Dabi Atlante, Ribeirão Preto, SP, Brazil). Five cavities were prepared for each group, using a molar with 3 cavities and the other one with 2 cavities. Light intensities were monitored using a radiometer (Model 100, Demetron Research Corp., Danbury, CT, USA). After curing, the additional molar was removed and the specimens were stored in distilled water at $37^{\circ} \mathrm{C}$ for 7 days to allow relaxation of stresses generated during composite polymerization.

\section{Evaluation of depth of cure}

After the storage period, teeth were embedded in PVC tubes using epoxy resin (Trok-Dente, Prodens, Rio de Janeiro, RJ, Brazil), so that buccal surfaces were resting against glass slabs. After polymerization, cavity surfaces were polished in a polishing machine (DPU-10, Struers, Copenhagen, Denmark) using 600, 1200 and 4000-grit sandpapers (3M, Campinas, SP, Brazil). A scale of 1.0-1.0 $\mathrm{mm}$ was then made on the polished longitudinal section of 
each composite restoration with the aid of a stereoscopic microscope (SZ 40, Olympus, Tokyo, Japan), under 20x magnification. Five indentations for KHN assessment were performed at each millimeter of each specimen under $20 \mathrm{~g}$ load, penetration period of $15 \mathrm{~s}$ and depth of $4 \mathrm{~mm}$ (2003, Buehler, Lake Bluff, USA).

\section{Statistical analysis}

The original data were analyzed using Statgraphics 5.1 Software. The KHN was the dependent variable, whereas depth of cure, composite resin materials and light-curing modes were independent factors. A normal distribution was verified and data were submitted to three-way ANOVA and Fisher's LSD test $(\alpha=0.01)$.

\section{RESULTS}

The results of KHN are summarized in Table 2. Threeway ANOVA revealed a statistically significant difference among resin composites $(\mathrm{p}<0.01)$, so that according to Fisher's LSD test, differences occurred among all tested materials (A $110<$ Admira < Z $250<$ Supreme < P 60). Regarding light-curing modes, values obtained for $\mathrm{C}$ and SS were statistically similar ( $>0.01$ ), but superior to those found for LED ( $<<0.01)$. P-60 and Admira demonstrated better performance when submitted to the conventional light-curing technique $(\mathrm{p}<0.01)$. A-110 showed similar values when submitted to $\mathrm{C}$ and SS light-curing modes, whereas the same was verified for $\mathrm{Z} 250$. Similar behavior was noticed for Supreme when submitted to SS and LED light-curing modes ( $p>0.01$ ). Table 2 shows that, except for A- 110 with $C$ and SS, P 60 with C and Z 250 with SS and LED light-curing modes, all other groups presented similar KHN values from first to second millimeter ( $\mathrm{p}>0.01$ ). Moreover, except for $\mathrm{Z}$ 250 with $C$ and $P 60$ with SS light-curing modes, there was a statistical difference between $\mathrm{KHN}$ values from first to third millimeter $(\mathrm{p}<0.01)$.

Figure 1 shows the percentage KHN reduction related to depth of cure. The percentage reduction was uniform up to $2 \mathrm{~mm}$ of depth for all evaluated light-curing modes. Below the second millimeter, this reduction was more noticeable for specimens submitted to LED, and remained similar for C and SS modes. From the third millimeter, the reduction was greater for SS group and smaller for the C group.

\section{DISCUSSION}

The existence of a correlation between monomer conversion and microhardness sustains the use of this variable to evaluate depth of cure of restorative composites ${ }^{12,24}$. Previous studies have used this

TABLE 1- Composition of dental composites used in the study

$\begin{array}{lll}\text { Composite Manufacturer } & \text { Composition }\end{array}$

P-60 3M ESPE, St Paul, MN, USA

Admira Voco, Anton-Flettner-Str., Cuxhaven, Germany

Z -250 3M ESPE, St Paul, MN, USA

Supreme $\quad 3 M$ ESPE, St Paul, MN, USA
Filler: $61 \%$ in volume and $83 \%$ wt of zircon silicate particles with distribution between $0.01-3.5 \mathrm{~mm}$ and mean particle size of $0.6 \mu \mathrm{m}$ Organic matrix: Bis-GMA, Bis-EMA, TEGDMA, UDMA

Filler: 3\% apatite-sulfate-phosphate and 77\% inorganic glass particles Ormocer matrix: polysiloxane -Si-O + methacrylate monomers

Filler: $60 \%$ in volume and $77.6 \%$ wt of zircon silicate particles. Mean particle size of $0.6 \mu \mathrm{m}$ Organic matrix: Bis-GMA, Bis-EMA, TEGDMA, UDMA

Filler: $78.5 \%$ wt of non-agglomerated silica nanoparticles with mean size of $20 \mathrm{~nm}$, and nano agglomerations composed of zircon-silica particles with a size varying from 5 to $20 \mathrm{~nm}$. Mean agglomeration size varied from 0.6 to $1.4 \mu \mathrm{m}$.

Organic matrix: Bis-GMA, Bis-EMA, TEGDMA, UDMA

Filler: $56 \%$ wt or $40 \%$ in volume of silica particles with mean size of $0.04 \mu \mathrm{m}$ (varying from 0.01 to $0.09 \mu \mathrm{m}$ ).

Organic matrix: Bis-GMA and TEGDMA. 
methodology $y^{3,18,20}$. However, great part of the authors employed specimens prepared using metallic or plastic matrices, with different optical properties from dental structures, a fact that may increase or reduce light transmission by light-curing units. Theoretically, this fact may also alter the obtained hardness measurements. In this study, specimens were prepared in cavities cut in human teeth with the purpose of simulating clinical conditions of light transmission that may occur during restorative procedures $^{20}$.

The depth of cure was assessed by means of percentage comparison of KHN obtained in various depths, so that KHN values for the first millimeter were considered as $100 \%{ }^{3,18,22}$. The percentage decrease in KHN with increased depths was similar for $\mathrm{C}$ and SS modes (Figure 1). From first to second millimeters this decrease was about $7.51 \%$ for C and $7.08 \%$ for SS groups. From second to third millimeters, the decrease was of $5.08 \%$ and $5.46 \%$, and from third to forth millimeters, reductions were of $7.11 \%$ and $12.06 \%$, respectively. Besides a uniform percentage reduction, absolute KHN values for both groups were also similar for all depths. Probably, this performance is related to the energy density achieved with both modes ${ }^{10}$. Although irradiation from these two sources is different, the final generated energy density was similar: $20 \mathrm{~J} / \mathrm{cm}^{2}$. This energy density might be enough to achieve satisfactory surface polymerization ${ }^{25}$ and would justify the observed decrease in deeper layers, where superior doses to $30 \mathrm{~J} / \mathrm{cm}^{2}$ can be necessary ${ }^{9}$. Despite their similar performance, it may be advocated that a soft-start polymerization technique is clinically more advantageous. Light-curing of composite materials using modes that gradually irradiate light, resulting in an increased pre-gel polymerization phase, would theoretically allow compensation of polymerization contraction and relaxation of contraction stresses, thus avoiding or reducing crack formation at the tooth-restoration interface $e^{4,8,10}$.

The use of LED within the parameters specified by its manufacturer (Dabi Atlante, Ribeirão Preto, SP, Brazil) had the objective to compare its efficacy with light-curing modes already evaluated in the literature. Although it has an emission spectrum with a peak of $468 \mathrm{~nm}$, corresponding to camphorquinone wavelength ${ }^{14,21}$, a photoinitiator present in all evaluated composites, its low light irradiance $(250 \mathrm{~mW} /$ $\mathrm{cm}^{2}$ ) may justify the poor performance obtained for this lightcuring mode. The calculated energy density considering this parameter and curing period of $40 \mathrm{~s}$ was $10 \mathrm{~J} / \mathrm{cm}^{2}$, an insufficient irradiation to provide effective composite polymerization $^{25}$. Besides showing a poorer performance when compared to $\mathrm{C}$ and SS modes, LED presented a reduced percentage on KHN values of 34.54\% between first and forth millimeters (Figure 1), a result that demonstrates unsatisfactory surface polymerization of the studied materials and increased loss of efficacy depending on the depth of cure. Although other published data from the literature demonstrated satisfactory results for light-curing modes using LEDs, it is important to emphasize that the units employed by the authors were in most part prototypes or had greater number of LEDs, consequently resulting in higher irradiation ${ }^{3,30}$. Hence, it is worth to conclude that despite the emission spectrum, LED units with low irradiation should be employed with longer exposure times to achieve necessary energy for an effective polymerization of lightcured composites ${ }^{16,17,18,25}$.

TABLE 2- $\mathrm{KHN} \pm \mathrm{SD}$ according to resin composite, light-curing mode and depth of cure

\begin{tabular}{|c|c|c|c|c|c|}
\hline Depth of cure & P 60 & Supreme & A 110 & Admira & Z 250 \\
\hline \multicolumn{6}{|c|}{ Conventional (C) } \\
\hline $1 \mathrm{~mm}$ & $98.9^{a}(2.3)$ & $72.7^{\mathrm{b}, \mathrm{c}} \pm 5.2$ & $62.8^{\mathrm{b}, \mathrm{c}} \pm 2.4$ & $71.2^{\mathrm{a}} \pm 2.8$ & $72,3^{\mathrm{b}, \mathrm{c}} \pm 4.1$ \\
\hline $2 \mathrm{~mm}$ & $86.7^{\mathrm{b}}(5.0)$ & $69.5^{\mathrm{c}, \mathrm{d}} \pm 1.3$ & $53.0^{d} \pm 2.9$ & $66.1^{\mathrm{a}, \mathrm{b}} \pm 2.2$ & $72.3^{b, c} \pm 2.1$ \\
\hline $3 \mathrm{~mm}$ & $81.9^{c}(5.0)$ & $66.1^{\mathrm{d}} 1.8$ & $50.4^{d} \pm 4.8$ & $62.5^{b, c} \pm 3.1$ & $69.5^{\mathrm{c}, \mathrm{d}} \pm 1.4$ \\
\hline $4 \mathrm{~mm}$ & $78.1^{\mathrm{c}}(1.0)$ & $59.3^{e} \pm 3.9$ & $41.5^{\mathrm{e}} \pm 1.3$ & $56.9^{\mathrm{d}, \mathrm{e}} \pm 1.9$ & $67.8^{\mathrm{c}, \mathrm{d}, \mathrm{e}} \pm 4.2$ \\
\hline \multicolumn{6}{|c|}{ Soft-Start (SS) } \\
\hline $1 \mathrm{~mm}$ & $83.2^{c} \pm 2.9$ & $86.4^{a} \pm 2.8$ & $69.7^{a} \pm 5.5$ & $66.6^{a, b} \pm 3.0$ & $83.5^{a} \pm 6.3$ \\
\hline $2 \mathrm{~mm}$ & $79.9^{c} \pm 3.5$ & $82.1^{a, b} \pm 2.5$ & $61.5^{\mathrm{b}, \mathrm{c}} \pm 4.7$ & $61.8^{\mathrm{b}, \mathrm{c}, \mathrm{d}} \pm 2.8$ & $76.5^{b} \pm 4.7$ \\
\hline $3 \mathrm{~mm}$ & $78.0^{\mathrm{c}, \mathrm{d}} \pm 2.2$ & $76.9^{b} \pm 4.0$ & $53.9^{d} \pm 6.1$ & $52.8^{e, f} \pm 5.4$ & $68.5^{\mathrm{c}, \mathrm{d}} \pm 4.8$ \\
\hline $4 \mathrm{~mm}$ & $69.7^{\mathrm{e}, \mathrm{f}} \pm 1.1$ & $66.1^{d} \pm 4.1$ & $41.4^{\mathrm{e}} \pm 5.4$ & $43.5^{g} \pm 8.0$ & $62.5^{e} \pm 2.6$ \\
\hline \multicolumn{6}{|c|}{ LED } \\
\hline $1 \mathrm{~mm}$ & $74.0^{\mathrm{d}, \mathrm{e}} \pm 5.1$ & $85.8^{a} \pm 6.5$ & $62.5^{\mathrm{b}, \mathrm{c}} \pm 3.7$ & $66.6^{\mathrm{a}, \mathrm{b}} \pm 6.1$ & $70.9^{c} \pm 5.2$ \\
\hline $2 \mathrm{~mm}$ & $72.5^{\mathrm{e}, \mathrm{f}} \pm 3.8$ & $82.1^{\mathrm{a}} \pm 3.8$ & $58.6^{c} \pm 0.9$ & $57.9^{c, d} \pm 3.0$ & $65.3^{\mathrm{d}, \mathrm{e}} \pm 4.7$ \\
\hline $3 \mathrm{~mm}$ & $68.2^{f} \pm 1.0$ & $74.2^{c} \pm 3.0$ & $48.7^{d} \pm 2.4$ & $48.4^{\mathrm{f}, \mathrm{g}} \pm 4.8$ & $53.3^{f} \pm 3.8$ \\
\hline $4 \mathrm{~mm}$ & $62.2^{g} \pm 2.3$ & $56.5^{\mathrm{e}} \pm 3.9$ & $34.4^{\dagger} \pm 3.5$ & $33.1^{h} \pm 2.0$ & $49.3^{f} \pm 2.3$ \\
\hline
\end{tabular}

* For each composite resin, mean values with the same superscript letters are not statistically different at $\alpha=0.01$ 
The depth of cure of restorative composites is influenced by organic and inorganic phases. Some studies demonstrated that increased concentration of filler particles improves hardness and depth of cure of light-cured composites ${ }^{7,29}$. This hypothesis confirms the results obtained in this study. The best performance presented by $\mathrm{P} 60$ for $\mathrm{C}$ light-curing mode can be related to its highest filler concentration (83\% wt). Probably, its organic phase also had influence on this performance. In this material, part of TEGDMA was substituted by UEDMA. UEDMA is a more flexible material than Bis-GMA ${ }^{27}$, and thus allows higher degree of conversion and forms hydrogen bonds throughout its urethane groups. This may influence the mechanical properties of light-cured composites ${ }^{1}$. Despite the similarities between P-60 and Z250 compositions (Table 1 ), their performance was different. An aspect that may justify this difference regards to the lower concentration in weight of filler particles for Z-250 (77.6\%). Considering the different viscosity of both materials, it may be speculated that Bis-GMA, Bis-EMA, TEGDMA and UEDMA concentrations are not the same, and may have influenced the degree of conversion of these materials and their mechanical properties ${ }^{1}$.

A-110 showed the worst performance, either regarding light-curing modes or depth of cure (Table 2). This may be related to its inorganic content. This material presents lower concentration of filler particles (56\% wt), with a diameter of approximately $0.04 \mathrm{~mm}$. Particles with these characteristics may increase light scattering and reduce the degree of polymerization of composite resins ${ }^{26}$. Theoretically, the nanometric filler particle content present in Supreme would cause the same effect of light scattering as in A-110. However, Supreme's behavior was similar to P-60 for SS up to the third millimeter and to Z 250 for $\mathrm{C}$ up to the third millimeter and for SS up to the second millimeter. Moreover, the best result for LED light-curing mode was presented by Supreme (Table $2)$. It was hypothesized that the higher concentration of nanometric particles (78.5\% wt) and the presence of zircon/ silica agglomerations with mean size varying between 0.6 and $1.4 \mathrm{~mm}$ may have minimized light scattering. Moreover, the presence of UEDMA in its organic matrix may have had the same influence as described above for P-60.

Except for A-110 with C and SS, P 60 with C and Z 250 with SS and LED light-curing modes, all other groups presented statistically similar KHN values from first to second millimeters (Table 2). This finding is in agreement with the classical concept that light-cured composite resins

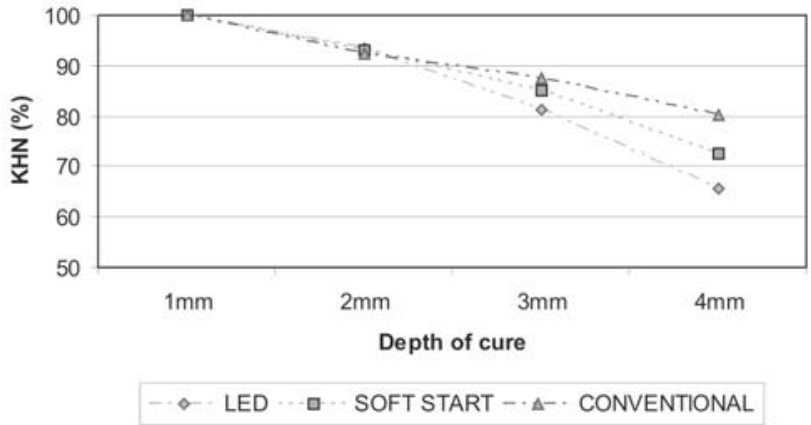

FIGURE 1- Percentage of KHN regarding depth of cure should not be placed in thicker increments than $2 \mathrm{~mm}$. Moreover, the performance of A-110 reinforces the negative influence of micro particles on the depth of cure of composite resins.

Although the obtained results for Admira were already referenced in previous published studies ${ }^{30}$, it was expected that its high concentration of filler particles (78\% wt) would provide a superior performance for this material. It may be speculated that its organic matrix contributed to the observed inferior results. This composite represents a new generation of materials that present ORMOCER matrix (organically modified ceramics). However, more studies are still necessary to correlate the effects of this organic matrix on its depth of cure.

\section{CONCLUSIONS}

The results obtained in this study support the proposed hypothesis that monomer composition present in the organic matrix, type and concentration of filler particles and lightcuring mode may influence depth of cure of resin composite materials. In addition, it may be concluded that energy density ( $\mathrm{t}(\mathrm{s}) \mathrm{x} \mathrm{mW} / \mathrm{cm}^{2}=\mathrm{J} / \mathrm{cm}^{2}$ ) is the most important factor on the effective polymerization of light-cured composites, and that material placement in thicker increments than $2 \mathrm{~mm}$ should be clinically avoided.

\section{REFERENCES}

1- Asmussen E, Peutzfeldt A. Influence of UEDMA, BisGMA and TEGDMA on selected mechanical properties of experimental resin composites. Dent Mater. 1998;14:51-6.

2- Asmussen E. NMR-analysis of monomers in restorative resins. Acta Odontol Scand. 1975;33:129-34.

3- Besnault C, Pradelle-Plasse N, Picard B, Colon P. Effect of a LED versus halogen light cure polymerization on the curing characteristics of three composite resins. Am J Dent. 2003;16:323-8.

4- Bouschlicher MR, Rueggeberg FA, Boyer DB. Effect of stepped light intensity on polymerization force and conversion in a photoactivated composite. J Esthet Dent. 2000;12:23-32.

5- Bowen RL. Dental filling material comprising vinyl-silane treated fused silica and a binder consisting of the reaction product of bisphenol and glycidyl methacrylate. US Patent 1962;3 066112.

6- Bowen RL. Properties of a silica-reinforced polymer for dental restorations. J Am Dent Assoc. 1963;66:57-64.

7- Chung KH. The relationship between composition and properties of posterior resin composites. J Dent Res. 1990;69:852-6.

8- Davidson CL, Feilzer AJ. Polymerization shrinkage and polymerization shrinkage stress in polymer-based restoratives. J Dent. 1997;25:435-40.

9- Emami N, Söderholm K-JM. How light irradiance and curing time affect monomer conversionin light-cured resin composites. Eur J Oral Sci. 2003;111:536-42. 
10- Emami N, Söderholm K-JM, Berglund LA. Effect of light power density variations on bulk curing properties of dental composites. J Dent. 2003;31:189-96.

11- Ferracane JL, Greener EH. The effect of resin formulation on the degree of conversion and mechanical properties of dental restorative resins. J Biomed Mater Res. 1986;20:121-31.

12- Ferracane JL. Correlation between hardness and degree of conversion during the setting reaction of unfilled dental restorative resins. Dent Mater. 1985;1:11-4

13- Ferracane JL, Aday P, Matsumoto H, Marker VA. Relationship between shade and depth of cure for light-activated dental composites resins. Dent Mater. 1986;2:80-4.

14- Jandt KD, Mills RW, Blackwell GB, Ashwort SH. Depth of cure and compressive strength of dental composite cured with blue light emitting diodes (LEDs). Dent Mater. 2000;16:41-7.

15- Koran P, Kurschner R. Effect of sequential versus continuous irradiation of a light-cured resin composite on shrinkage, viscosity, adhesion, and degree of polymerization. Am J Dent. 1998;11:17-22.

16- Kurachi C, Tuboy AM, Magalhaes DV, Bagnato VS. Hardness evaluation of a dental composite polymerized with experimental LED - based devices. Dent Mater. 2001;17:309-15.

17- Leonard DL, Charlton DG, Roberts HW, Cohen ME. Polymerization efficiency of LED curing Lights. J Esthet Restor Dent. 2002;14:286-95.

18- Li Y, Swartz ML, Phillips RW, Moore BK, Roberts TA. Effect of filler content and size on properties of composites. J Dent Res. 1985;64:1396-401.

19- Martin FE. A survey of the efficiency of visible light curing units J Dent. 1998;26:239-43.

20- Matsumoto H, Gres JE, Marker VA, Okabe T, Ferracane JL, Harvey GA. Depth of cure of visible light-cure resin: Clinical Simulation. J Prosthet Dent. 1986;55:574-8.

21- Mills RW, Jandt KD, Ashworth SH. Dental composite depth of cure with halogen and blue light emitting diode technology. $\mathrm{Br}$ Dent J. 1999;186:388-91.

22- Neves AD, Discacciati JAC, Oréfice RL, Jansen WC. Correlation between degree of conversion, microhardness and inorganic content in composites. Pesqui Odontol Bras. 2002;16:349-54.

23- Peutzfeldt A, Asmussen E. In vitro wear, hardness and conversion of diacetyl-containing and propanal-containing resin materials. Dent Mater. 1996;12:103-8.

24- Rueggeberg FA, Craig RG. Correlation of parameters used to estimate monomer conversion in a light-cure composite. J Dent Res. 1988;67:932-7

25- Rueggeberg FA, Caughman WF, Curtis JW Jr. Effect of light intensity and exposure duration on cure of resin composite. Oper Dent. 1994;19:26-32.

26- Ruyter IE, Øysaed H. Conversion in different depths of ultraviolet and visible light activated composite materials. Acta Odontol Scand. 1982;40:179-92.

27- Ruyter IE, Øysaed H. Composites for use in posterior teeth: composition and conversion. J Biomed Mater Res. 1987;21:11-23.

28- Schmitt W, Purrmann R, Jochum P, Zahler WD. Novel diacrylic and dimethacrylic acid esters. US Patent 1974;3,810,938.
29- St Germain H, Swartz ML, Phillips RW, Moore BK, Roberts TA. Properties of microfilled composite resin as influenced by filler content. J Dent Res. 1985;64:155-60.

30- Uhl A, Sigusch BW, Jandt KD. Second generation LEDs for the polymerization of oral biomaterials. Dent Mater. 2004;20:80-7. 